\title{
Biochar: A Potential Alternative for Sustainable Agriculture
}

\author{
Harender Singh Dahiya* and Yogendra Kumar Budania \\ State Agriculture Department, Government of Haryana, India \\ *Corresponding author
}

\begin{abstract}
A B S T R A C T
Keywords

Biochar, Climate change,

Mitigation, Adaptation

and Environmental

sustainability

Article Info

Accepted:

04 September 2018

Available Online:

10 October 2018

Climate is one of the key drivers behind agriculture. As climate change is uncertain, agriculture should be climate smart and must include agricultural management practices which include the use of bio wastes that could be able to sustain or improve our soil health. Moreover, increase in atmospheric carbon level is becoming a challenging task for the scientific community. Worldwide, successful implement strategies are being developing to drop down carbon dioxide level from the atmosphere but climate change is a becoming a bigger threat to civilization day by day which must be tackled. Biochar, due to its aromatic structure and long mean residence time in the soil has the potential for long-term carbon sequestration in the soil and offers a significant tool to reduce $\mathrm{CO}_{2}$ and $\mathrm{GHG}$ emissions. The trend obtained from the research studies carried out across the world raised our hopes of achieving the goal of maintain or enhancing the crop productivity coupled with environmental sustainability. Therefore, this paper aims to raise awareness among the scientific community about the use of biochar as a sustainable option for climate change mitigation and adaptation.
\end{abstract}

\section{Introduction}

The world's population currently stands at just over 6.7 billion and is projected to surpass 9 billion by 2050 (Human Development Report, 2016). Therefore, the key role of agriculture now and in future is to provide safe and quality food for ever growing population. Moreover, agriculture is of more significance to climate change due to emissions in food production and emissions through land use and management change. Collectively, these account for carbon-equivalent emissions equal, globally, to that of transport and since agricultural emissions are affected by fertilizer application and the extent of the livestock sector, agriculture has to address at the same time three knotted challenges, first, ensuring food safety through increased income and productivity, second, adapting to climate change and third is contributing to climate change mitigation. It is in this context that biochar has emerged as a potential strategy for climate change mitigation and sustainable food production at the global scale. Biochar comprises biomass in a deliberately stabilized form, for which the soil may provide storage on a very large scale. With requisite physical and chemical properties, these forms of carbon could still offer potential value to crop productivity through dynamic or reversible interactions with nutrients and soil mineral 
particles. It has been well recognized as carbon-enriched material intended to be used as a soil amendment in agriculture to sequester carbon and enhance soil quality. Sustainable biochar is produced from waste biomass using modern thermo chemical technologies. Addition of sustainable biochar to soil has many environmental and agricultural benefits, including waste reduction, energy production, carbon sequestration, water resource protection, and soil improvement. Therefore, the use of sustainable biochar as a soil amendment is an innovative and highly promising practice for sustainable agriculture.

Any improvement to the productivity of existing agricultural land has the potential to relieve the pressure on biodiverse and often carbon rich natural ecosystems. The potential for biochar to capture and store carbon in soils, and therefore its potential role as a GHG mitigation option, is currently also attracting attention globally, in both academic and government spheres. Analyses have suggested that the annual potential for sequestration of atmospheric carbon dioxide $\left(\mathrm{CO}_{2}\right)$ globally could be at the billion-tonne scale within 30 years (Woolf, 2010; Lehmann et al., 2009). Matovic (2011) estimated that charring and burying $10 \%$ of global net primary productivity each year would offset the current annual increase in atmospheric $\mathrm{CO}_{2}$. As a result of such analyses, the discussion around biochar has moved from scientific studies to specific policy proposals for carbon offsets (De Gryze et al., 2010). Brick and Lyutse (2010), for example, published a report that assessed the major risks and potential around biochar production to help inform the development of specific policies in the USA. Similarly, Amezaga et al., 2010 have looked at the role biochar could play in the framework they developed for the policy evaluation of bioenergy projects in the developing world. Sustainable biochar is produced from sustainably procured waste biomass such as crop residues, manures, timber and forestry residues, and green waste using modern pyrolysis technology (Woolf et al., 2010). Therefore, sustainable biochar production and its use as a soil amendment have been suggested as a means of abating climate change by sequestering carbon, while simultaneously reducing waste, improving soil quality, and protecting natural resource (Winsley, 2007; Laird, 2008; Zheng et al., 2010). There is extensive research continuing world-wide aimed at developing biochar's demonstrated success, but the research is largely focused on direct applications or specific benefits such as improvement in soil quality encompassing making nutrients more available over time, increased carbon sequestration, ground water retention, hazardous waste mitigation, land remediation, forest/biomass utilization, and renewable energy generation. Biochar is increasingly receiving attention and highly recommended as soil amendment because it cannot only mitigate climate change by sequestrating $\mathrm{C}$ from atmosphere into soil (Marris, 2006; Lehmann, 2007) but also improve soil properties and enhance soil fertility by improving moisture and nutrients retention (Lehmann et al., 2006) and microbial activity (Lehmann et al., 2011) hence increasing crop productivity. Several kinds of biomass canserve as source materials of biochar, for example, woodchips, animal manure, crop residues. In this sense, enhancing recycles of agricultural and forestry wastes (Luo et al., 2011) is also a noticeable advantage of biochar. These diverse potential benefits, incorporated with the fact that biochar produced from a range of biomass can potentially be a relatively cost-effective and environmental beneficial tool for environmental remediation, stimulates increasing research on biochar. With the need for global carbon sequestering strategies, further research into the wide-scale uses of biochar as a soil amendment and as a toxin 
adsorbent are needed, as well as quantification of its carbon sequestration capability.

\section{What is biochar?}

Biochar is a term for charcoal that is used for biological ends, such as a soil amendment, as opposed to heat. It is defined as a fine-grained and porous substance, similar in its appearance to charcoal produced by natural burning or Biochar, also known as black carbon, is a product derived from organic materials rich in carbon $(\mathrm{C})$ and is found in soils in very stable solid forms, often as deposits. Biochars can persist for long periods of time in the soil at various depths, typically thousands of years. The most common example is charcoal, derived from wood. The benefical effects of biochar were discovered more than 2,000 years ago when the "slashand-burn" agricultural method was in practice. Natural forest fires and historical cultural practices also resulted in the formation of biochars that are stable over thousands of years as soil deposits.

\section{How biochar can be produced}

Biochar is produced by heating biomass (feedstock). The feedstock undergoes thermal decomposition and is reduced to a carbon-rich residue, a process known as carbonization. A range of thermal conversion processes can be used to produce carbon products which include biochar. Torrefaction, pyrolysis, gasification, hydrothermal carbonisation, and combinations of these 2 may all be used in char production

\section{Torrefaction}

Torrefaction is a thermochemical treatment of biomass at 200 to $320{ }^{\circ} \mathrm{C}\left(392\right.$ to $\left.608^{\circ} \mathrm{F}\right)$. It is carried out under atmospheric pressure and in the absence of oxygen, i.e. with no air. During the torrefaction process, the water contained in the biomass as well as superfluous volatiles are released, and the biopolymers (cellulose, hemicellulose and lignin) partly decompose, giving off various types of volatiles (Bates and Ghoniem, 2012). The final product is the remaining solid, dry, blackened material [Dutch Torrefaction Association (DTA), 2012] that is referred to as torrefied biomass or bio-coal.

\section{Pyrolysis}

Pyrolysis is a thermal decomposition of materials at elevated temperatures in an inert atmosphere such as a vacuum or nitrogen gas. It involves the change of chemical composition and is irreversible. The word is coined from the Greek-derived elements pyro "fire" and lysis "separating". Pyrolysis is most commonly applied to the treatment of organic materials. It is one of the processes involved in charring wood, starting at 200$300{ }^{\circ} \mathrm{C}\left(390-570{ }^{\circ} \mathrm{F}\right)$ (Anonymous, 2010). In general, pyrolysis of organic substances produces volatile products and leaves a solid residue enriched in carbon, char. Extreme pyrolysis, which leaves mostly carbon as the residue, is called carbonization. The process is used heavily in the chemical industry, for example, to produce ethylene, many forms of carbon, and other chemicals from petroleum, coal, and even wood, to produce coke from coal. Certain uses of pyrolysis are called dry distillation, destructive distillation, or cracking. The processes involve thermal depolymerization, i.e. the breaking of chemical bonds in macromolecules to give smaller fragments. The phenomenon involves exceeding the ceiling temperature of polymers. Pyrolysis is the basis of several methods for producing fuel from biomass, i.e. lignocellulosic biomass (Evans, 2008). Crops studied as biomass feedstock for pyrolysis include native North American prairie grasses such as switch grass and bred versions of other grasses such as Miscantheu sgiganteus. Other 
sources of organic matter as feedstock for pyrolysis include greenwaste, sawdust, waste wood, nut shells, straw, cotton trash, rice hulls. Animal waste including poultry litter, dairy manure, and potentially other manures are also under evaluation. Pyrolysis differs from other processes like combustion and hydrolysis in that it usually does not involve the addition of other reagents such as oxygen $\left(\mathrm{O}_{2}\right.$, in combustion) or water (in hydrolysis) (Cory et al., 2009). In practice, it is often not practical to achieve a completely $\mathrm{O}_{2}$ or water free conditions, especially as pyrolysis is often conducted on complex mixtures.

The term has also been applied to the decomposition of organic material in the presence of superheated water or steam (hydrous pyrolysis), for example, in the steam cracking of oil. Pyrolysis has been assumed to take place during catagenesis, the conversion of buried organic matter to fossil fuels. In vacuum pyrolysis, organic material is heated in a vacuum to decrease its boiling point and avoid adverse chemical reactions. Called flash vacuum pyrolysis, this approach is used in organic synthesis.

\section{Gasification}

Gasification is a process that converts organicor fossil fuel-based carbonaceous materials into carbon monoxide, hydrogen and carbon dioxide. This is achieved by reacting the material at high temperatures $\left(>700{ }^{\circ} \mathrm{C}\right)$, without combustion, with a controlled amount of oxygen and/or steam. The resulting gas mixture is called syngas (from synthesis gas) or producer gas and is itself a fuel. The power derived from gasification and combustion of the resultant gas is considered to be a source of renewable energy if the gasified compounds were obtained from biomass. Gasification can also begin with material for biochar production which would otherwise have been disposed of such as biodegradable waste.

\section{Hydrothermal carbonisation}

Hydrothermal carbonization (HTC) (also referred to as "aqueous carbonization at elevated temperature and pressure") is a chemical process for the conversion of organic compounds to structured carbons. It can be used to make a wide variety of nanostructured carbons, simple production of brown coal substitute, synthesis gas, liquid petroleum precursors and humus from biomass with release of energy.

Hydrothermal carbonisation, also known as wet pyrolysis, heats biomass and water for hours to days to $180-220^{\circ} \mathrm{C}$ in a sealed vessel under pressure to produce a lignite-like material (Meyer et. al., 2011). These materials tend to be best suited for energy purposes (e.g. co-firing in coal fired power station).

\section{Activation}

The process of activation subjects pyrolised material to partial gasification at high temperatures greater than $700^{\circ} \mathrm{C}$ with steam, carbon dioxide or a mixture of the two to produce material that can have a more porous structure and increased surface area (Downie et al., 2009).

\section{Factors affecting characteristics of biochar}

Feedstock/ raw material type

Method of preparation of the feedstock/ raw material for biochar production

Temperature

Production residence time

Heating rate i.e. fast or slow

Maintenance of oxygen level during production 


\section{Feedstock/ raw material type}

Sugar cane bagasse, coconut husk, nut shells, and tobacco waste are particularly suitable for pyrolysis, but other suitable biomass materials from agriculture include broadacre grain trash/stubble, wood chips and tree bark, grass residues, animal bedding, livestock manure and chicken litter. Municipal waste has great potential given the constant supply, but in industrial areas may contain high levels of toxic substances which will make the biochar unsuitable for agricultural soils (Sparkes and Stoutjesdijk, 2011).

The viability of biochar production depends on having large quantities of feedstock close by to minimise transport costs. This means the larger pyrolysis plants need to be located in areas near to large quantities of biomass feedstock.

\section{Feedstock preparation}

Feedstock physical properties such as particle size, moisture content, and contaminant levels all affect biochar quality. The size of feedstock pieces affects the rate of heat transfer into, and the rate of gas transfer out of, each piece (Downie et al., 2009). In large particle feedstock the transfer of heat into the particles is slower and transfer of volatiles out is also slower, so feedstocks may need to be broken into small pieces to facilitate pyrolysis. Fast pyrolysis production systems require all feedstocks to be pre-processed to allow the high temperatures to penetrate all particles very quickly.

\section{Production temperature}

Woody biochars produced at temperatures above $600^{\circ} \mathrm{C}$ are generally more likely to be stable and have greater porosity and adsorptive capabilities than biochars produced at lower temperatures. The improved porosity is due to the volatilisation of tars and impurities that clog the biochar's finer pores and reduce pore connectivity (Downie et al., 2009). As a general rule, an increase in highest temperature attained during pyrolysis (HTT) leads to an increase in the surface area of biochar which makes it more adsorptive for chemical reactions (Downie et al., 2009). However, when high HTT is combined with a feedstock that has an inorganic component with a melting point lower than the HTT, the biochar pores fill with inorganic compounds and reduces the surface area of the biochar (Downie et al., 2009). At lower temperatures $\left(300-400^{\circ} \mathrm{C}\right)$ carbonisation is only partially achieved and biochar will have smaller pores and lower surface area (Amonette and Joseph, 2009).

\section{Residence time}

In biochar production the term residence time refers to the time a feedstock is held within a constant temperature range and a given carbonisation process (International Biochar Initiative, 2012b). The combination of high temperature and longer residence times allows carbonisation reactions to be completed, resulting in biochars that have lower $\mathrm{H}$ : $\mathrm{C}$ ratios (which tend to be more stable), and are likely to have larger surface area.

\section{Heating rate}

Heating rates and pressures are important factors determining properties of biochars (Downie et al., 2009). The faster the heating rate, the smaller the particle size needed to ensure that heat passes all the way through the particle. Thus fast pyrolysis completed in a few seconds needs powdered feedstock particles. Slow pyrolysis is used for larger feedstock particles to ensure they carbonise completely. Fast pyrolysis encourages formation of bio-oil, and slow pyrolysis is more commonly used for biochar. 


\section{Oxygen level}

Biochar production requires low levels of oxygen to ensure that biomass converts to solid carbon rather than combusting to produce carbon monoxide, carbon dioxide and ash. High oxygen levels move production systems towards more complete combustion, so are used to produce gas and energy (and some ash) rather than biochar.

\section{Properties of biochar}

A biochar containing more ash is generally less energy-efficient. However, for plant growth, ash can be considered a desirable mineral amendment as long as its heavy metal content does not exceed environmental standards. Agricultural applications of ashes are sometimes made. For the purposes of soil carbon sequestration or organic amendment, however, biochars should contain less ash and as much carbon as possible. The percentage of ash in the biochars can vary between 1 and $54 \%$ of dry weight. Many biochars have a neutral to alkaline $\mathrm{pH}$, so can provide some benefit in neutralising acidic soils. However this alkalinity may be detrimental when applied to soils with neutral or alkaline $\mathrm{pH}$ values, as reductions in plant productivity have been demonstrated when alkaline biochars are added to a Calcarosol (Van et al., 2010c).

\section{Environmental risks of biochar production}

One of the great benefits of biochar, from a long-term carbon sequestration perspective, is that once it is applied to soil there is no practical way to remove it again.

This also presents an alarming challenge and a critical onus on ensuring that the product is suitable for use before it is applied, because once it is applied the damage done may be irreversible.
The main risk factors that may result in a biochar not being suitable for use are:

Contamination, such as heavy metals (Veeken and Hamelers, 2002), poly-aromatic hydrocarbons (PAH) (Brandli et al., 2007), bulk metals, glass, ceramics, dioxins etc.

Characteristics that amplify existing constraints (e.g. applying a high $\mathrm{pH}$ biochar to an already high $\mathrm{pH}$ soil making the issue of alkalinity worse, or a hydrophobic biochar to soils limited by lack of water penetration).

Biochar products should be tested to ensure levels of contaminants are below background levels and/or meet local environmental regulations. Contaminants can result both from operational conditions (e.g. PAH, dioxins and furans can be generated as a result of the thermal processing), and the feedstock (e.g. heavy metals in treated timbers).

\section{Effect of biochar application on soil properties}

Soil improvement is not a luxury but a necessity in many regions of the world. Lack of food security is especially common in subSaharan Africa and South Asia, with malnutrition in 32 and 22 per cent of the total population, respectively (FAO, 2006). In both industrialized and developing countries, soil loss and degradation is occurring at unprecedented rates (Stocking, 2003; IAASTD, 2008), with profound consequences for soil ecosystem properties (Matson et al., 1997). In many regions, loss in soil productivity occurs despite intensive use of agrochemicals, concurrent with adverse environmental impact on soil and water resources (Foley et al., 2005). Biochar is able to play a major role in expanding options for sustainable soil management by improving upon existing best management practices, not only to improve soil productivity but also to 
decrease environmental impact on soil and water resources. Biochar should therefore not be seen as an alternative to existing soil management, but as a valuable addition that facilitates the development of sustainable land use: creating a truly green 'Biochar Revolution'.

\section{Influence of biochar on soil carbon}

Biochars are recalcitrant organic materials, which means they are highly resistant to biological and chemical decomposition (McBeath and Smernik, 2009; Zimmerman, 2010). The rate and extent of biochar decomposition in soil depends on type of feedstock and pyrolysis conditions, (Singh and Cowie, 2010; Zimmerman, 2010) soil organic matter levels (Keith et al., 2011; Luo et al., 2011), soil type (Luo et al., 2011) and environmental conditions (Nguyen and Lehmann, 2009; Nguyen et al., 2010).

The mean residence time (MRT) of biochars in soil has been estimated to range from several decades (usually $>100$ years) to millennia as determined mainly through laboratory incubation studies (Kuzyakov et al., 2009; Singh and Cowie, 2010; Zimmerman, 2010). This high stability is an important factor in biochar's potential to mitigate greenhouse gas emissions from soil (Woolf et al., 2010; Slavich et al., 2012).

Biochar has been shown to both stimulate (positive priming) and suppress (negative priming) the breakdown of existing soil organic carbon, which can negate or enhance the carbon sequestration benefits of biochar application to soil (Wardle et al., 2009; Zimmerman et al., 2011). Luo et al., (2011) in his study has recently shown that biochar application can stimulate the decomposition rate of native soil organic carbon due to increases in biological activity following biochar application; however, this loss of native soil organic carbon occurs only directly following application of the biochar and is not likely to be a long-term effect.

Impacts on plant germination and establishment

Biochar can contain organic compounds that may impact plant germination and growth (Rogovska et al., 2010). These include nitrogen-heterocyclics, substituted furans, phenols and substituted phenols, benzene and substituted benzene, carboxylics and aliphatics. The compounds vary according to production conditions and feedstock materials, both of which may influence potential phytotoxicity. For example, a study conducted by Kwapinski et al., (2010) showed that the growth of maize seedlings was inhibited with biochar from Miscanthus (a type of giant grass) made at $400^{\circ} \mathrm{C}$, but stimulated by Miscanthus biochar made at $600^{\circ} \mathrm{C}$. Extracts from biochars produced by gasification contained compounds that suppressed seedling growth (Rogovska et al., 2010). However, extracts from biochars produced from the same feedstocks through pyrolysis $\left(\mathrm{ca} .500^{\circ} \mathrm{C}\right.$ ) did not impact on either germination or seedling growth. Rogovska et al., (2010) suggested that ageing of the biochars in soil would result in removal of phytotoxic effects.

Different researchers (Keller et al., 2010) undertook an experiment to test the impacts of tar-enriched biochar (fast pyrolysis at $600^{\circ} \mathrm{C}$ ) on phytotoxicity. The authors noted that even with tar-enriched biochar amendment up to $10 \%$ by weight in soil, germination and seedling growth of lettuce increased. Another group tested the impact of feedstocks (biosolids, corn stover, eucalyptus, fresh pine and willow) on biochar properties (all pyrolysed at $550^{\circ} \mathrm{C}$ ). No effect on seedling germination was observed when these were applied at rates up to 10t/ha into soil (Free et al., 2010). 


\section{Biochar influences on nutrient availability in soil}

\section{Nitrogen}

There is mounting evidence that biochars of plant origin with generally low nutrient value can improve nitrogen use efficiency when amended into soil (Chan et al., 2007). In most applications of nitrogen fertiliser, less than $50 \%$ of the nitrogen is taken up by the crop (Baligar and Bennett, 1986). Biochar application may benefit farm returns and the environment through improving nitrogen use efficiency, by processes such as reducing offfarm loss of nitrogen-based fertiliser.

The changes in nitrogen dynamics, including emissions of nitrous oxide, following biochar application are still under investigation (Clough et al., 2010; Lehmann, 2007). Biochar may bind inorganic nitrogen, which would reduce the rate of nitrogen cycling, including $\mathrm{N}_{2} \mathrm{O}$ emissions, e.g. via nitrification and denitrification. Weathering of biochar in soil may also immobilise nitrogen (Singh et al., 2010; Yao et al., 2010). Biochar can reduce leaching of ammonium in soil depending on the properties of the biochar and the characteristics of the soil.

This occurs through development of exchange sites of biochar surfaces (Joseph et al., 2010; Lin et al., 2012), which in turn is influenced by the ageing and interaction of biochar with soil constituents. Biochar application may increase the rate of nitrification (conversion of ammonia to nitrate) in Ferrosols, (Dandie et al., 2011; Van et al., 2009) possibly due to increased soil $\mathrm{pH}$ and more favourable conditions for nitrifying organisms.

\section{Soil type}

Biochar's effect on soil nutrient status depends on both the soil and the biochar. In one trial,
NSW researchers (Slavich et al., 2012) noted long-term increases in plant available phosphorus in acidic Ferrosols following amendment with animal manure biochar, but no increase after amendment with a greenwaste biochar on the same soil (both biochars produced at 5500C).

These biochars had contrasting properties, especially nutrient content. A complimentary study by Wang et al., (2012) showed that phosphorus from high-ash biochars, such as those originating from manure feedstocks, and having a high total phosphorus concentration, are potential phosphorus sources with highagronomic efficiency. Conversely, high rates of greenwaste biochar $(4.4 \%$ and $11 \%, \mathrm{w} / \mathrm{w})$ applied to a Tenosol used for commercial vegetable production in NSW resulted in a small reduction in plant available phosphorus (Van et al., 2010c).

\section{Influence of biochar on soil biology}

\section{Beneficial organisms}

Biochar addition may increase soil microbial biomass (population size), and affect microbial community structure (species present) and enzyme activities (Awad et al., 2012; Bailey et al., 2011; Jin, 2010). Chan et al., (2008b) observed an increase in microbial biomass in the presence of poultry litter biochar in a hard-setting soil growing radishes. While increased microbial biomass has been observed, it has often been accompanied by a reduction in microbial activity (Steiner et al., 2008; Jin, 2010), most probably due to sorption of labile organics, nutrients, and enzymes on the biochar. Biochar application has been shown to increase the rate of mycorrhizal fungal colonisation in roots, although it depends on the biochar, soil type and plant species (Ogawa and Okimori, 2010; Blackwell et al., 2010). 

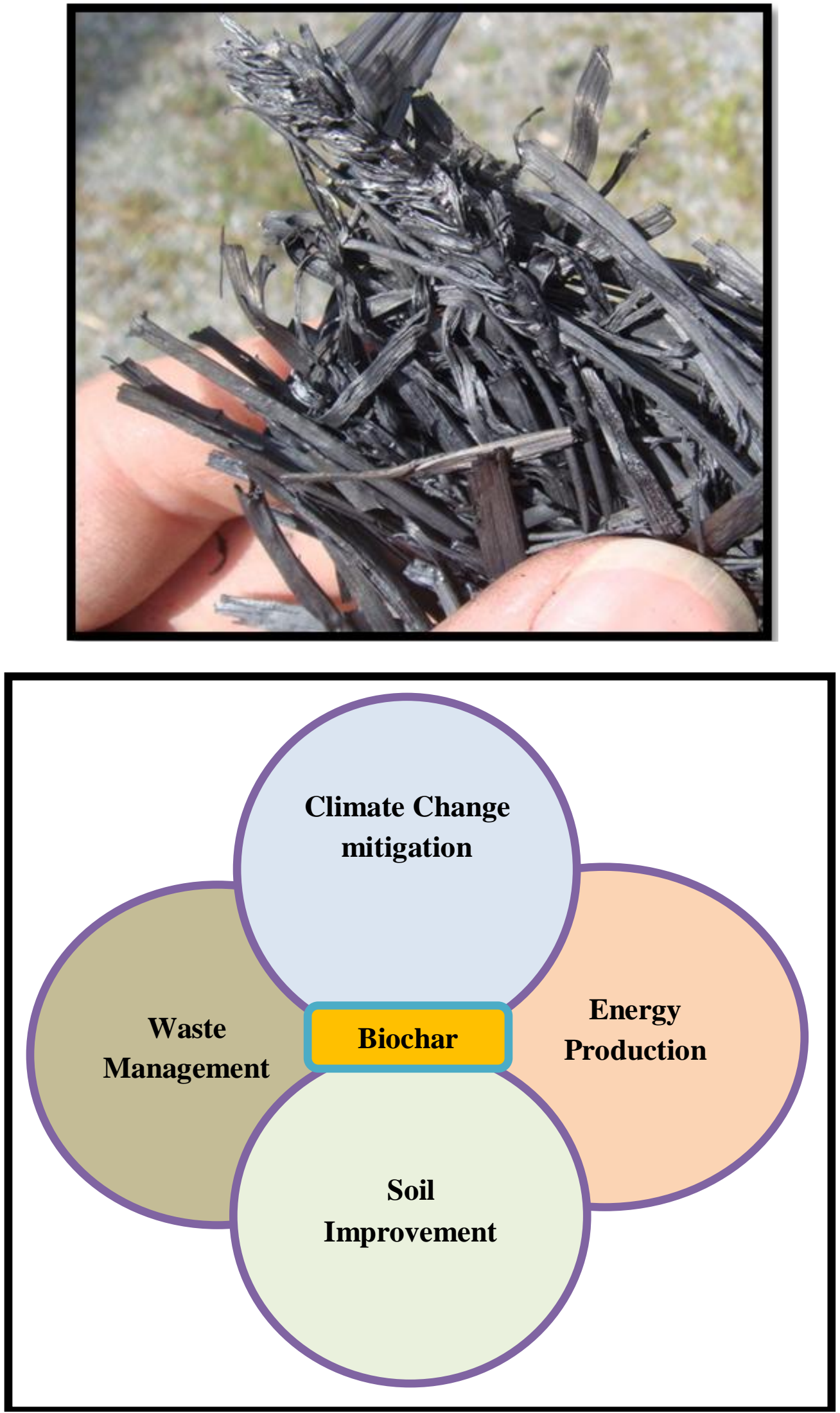
Flow chart showing factors affecting biochar properties

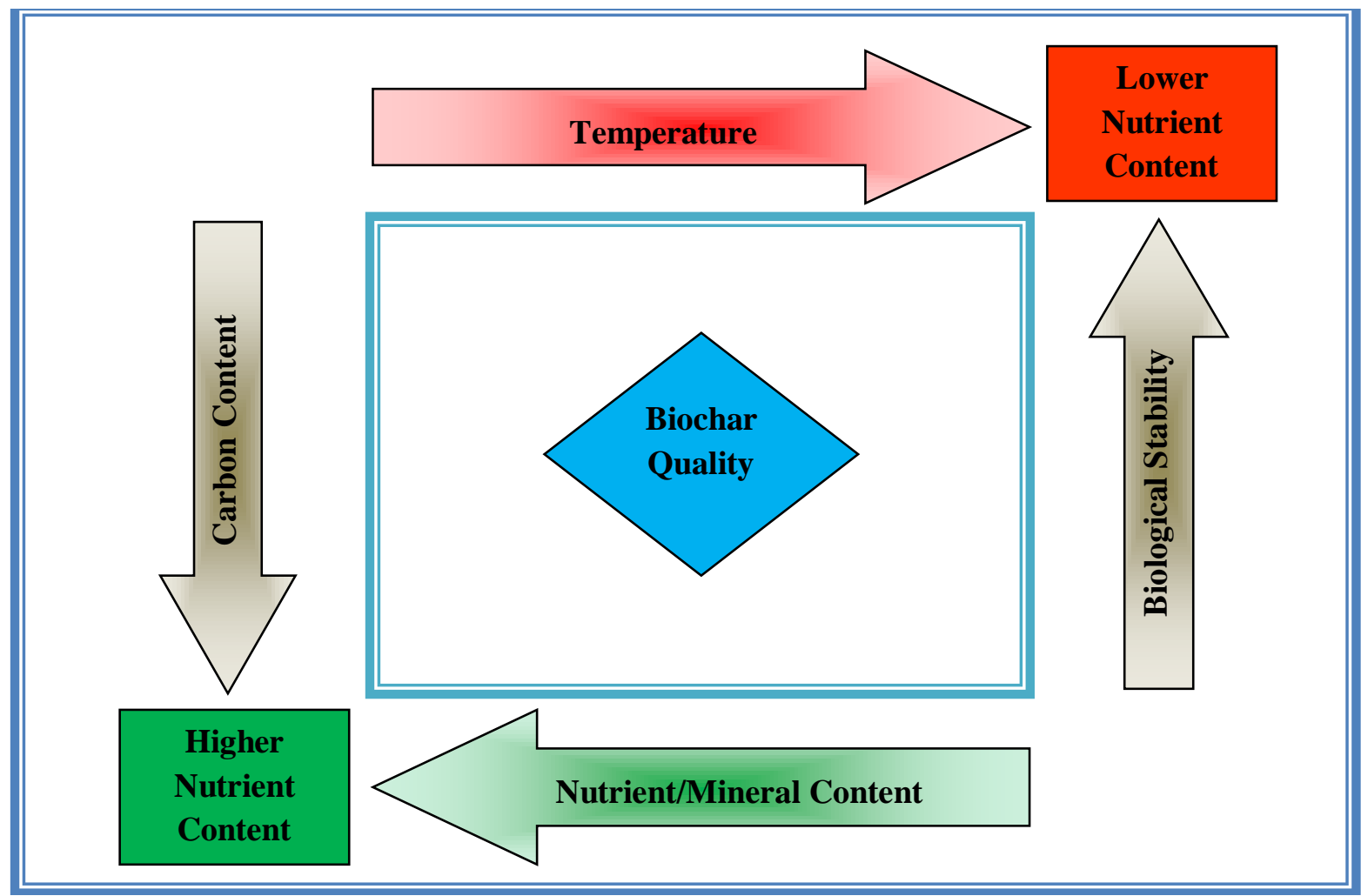

A much cited review of published studies on this topic attempted to determine the causes for the increased colonisation and concluded that there were four possible mechanisms.

Biochar favourably alters the physical and chemical properties of the soil, especially availability of nutrients,

It may affect other microbial populations and indirectly encourage mycorrhizae.

It can influence the signalling chemicals between plants and fungi.

It may provide habitat that protects fungi from fungal grazers.

\section{Soil fauna}

There is little information currently available on the impact of biochar on soil faunal groups. Earthworms are the most studied soil fauna, possibly because they ingest soil (and biochar) and show greater sensitivity to changes in soil conditions than other soil faunal groups. Results to date are inconclusive: earthworms have avoided (Liesch et al., 2010), and shown no preference to soil amended with biochar (Chan et al., 2008b). A recent review concluded that there were some short term negative impacts, but in the longer term earthworm population density and size were not affected by biochar. Negative impacts occurred because the biochar was too dry, too alkaline or affected feeding behavior. These variable impacts of biochar on earthworms highlight the need for further research to underpin biochar use in horticultural systems, to ensure that it enhances beneficial organisms and, consequently, productivity. An earthworm avoidance assay has been included in guidelines developed by the 
International Biochar Initiative to minimise any potential impacts of biochars on soil fauna (International Biochar Initiative, 2012b).

\section{Influence of biochar on soil physical conditions}

Tryon in 1948 in his early study reported that using charcoal amendment to soil showed significant increases in retention of water in sandy soils, and reduced retention of water in clay soils. This varied response highlights the importance of understanding the specific soil constraint, and the ability of biochar to address the constraint. Glaser et al., (2002) reported an $18 \%$ increase in field capacity for high black carbon Anthroposols (soils formed by human activity) compared with surrounding low black carbon soils, and attributed this to the increased surface area and porous structure of the char particles. It should be noted however that these Anthroposols had a high level of charcoal addition over many years (amounting to up to hundreds of tonnes per hectare). Biochar was reported to enhance saturated hydraulic conductivity and water-holding capacity in upland rice production in Northern Laos (Asai et al., 2009). In a study on upland sandy soils, a study conducted by Uzoma et al., (2011) found that application of biochar increased the available water by $97 \%$, saturated water content by $56 \%$, and reduced hydraulic conductivity with increasing moisture content when compared with unamended sand. However, improvements in water holding capacity depend on the biochar and the soil (Streubel et al., 2011), with the physical structure of the biochar having the greatest influence. This evidence suggests that biochars possess the potential to improve water use efficiency and productivity in water-limited conditions. Increases in soil organic matter have been shown to enhance soil aggregate stability (Chan et al., 2003;
Conyers, 2012). It could be argued that biochar amendment is not the best form of organic matter to achieve increased soil aggregation, but its stable nature is likely to contribute to aggregation over the long term (Busscher et al., 2011). Biochar may contribute to the physical stabilisation of other soil organic matter which could further enhance structure. Australian researchers, Chan et al., (2007) reported significant reduction in soil tensile strength following application of high rates of greenwaste biochar in a hardsetting soil (which could enhance seedling emergence, root growth and water infiltration, and reduce fuel use in cultivation), but further data on impacts on tensile strength are lacking. Biochar tends to be a low density product (Downie et al., 2009), so its application to soil would be expected to reduce bulk density.

Adoption of biochar-based strategies for energy production, soil management and $\mathrm{C}$ sequestration relies primarily on farmer community. But government can also play a critical role by facilitating the process of technological development, especially in the initial phases of research and development. Although biochar has great potential to become a critical intervention in addressing key future challenges, it is best seen as an important 'wedge', contributing to an overall portfolio of strategies in agriculture. Concerns over using biomass resources that would otherwise fulfil ecosystem services or human needs have to be taken into full consideration. Possible conflicts of producing energy and biochar versus food as a consequence of massive adoption of biochar technologies have to be considered, while biochar will undoubtedly improve soil quality and productivity, some soil cover is required to keep water and wind erosion at a minimum. Therefore, plant residues cannot be entirely removed for biochar production. Other tasks that lie ahead are technological issues, such as 
refining methods for production, transportation of biochar and its application to soil, while avoiding unacceptable dust form.

\section{References}

Amezaga, J. M., Von, M. G. and Boyes, S. 2010. Assessing the sustainability of bioenergy projectsin developing countries: a framework for policy evaluation. Newcastle: Newcastle University.

Amonette, J. E. and Joseph, S. 2009. Characteristics of biochar: microchemical properties. In 'Biochar for environmental management: Science and Technology.' (Eds J Lehmann and $S$ Joseph) pp. 33-52. Earthscan: London; Sterling, VA, USA.

Anonymous, 2010. Burning of wood, Inno Fire Wood's website. Accessed on 2010-02-06.

Asai, H., Samson, B. K., Stephan, H. M., Songyikhangsuthor, K., Homma, K., Kiyono, Y., Inoue, Y., Shiraiwa, T. and Horie, T. 2009. Biochar amendment techniques for upland rice production in Northern Laos: 1. Soil physical properties, leaf SPAD and grain yield. Field Crops Res. 111(1/2): 81-84.

Awad, Y. M., Blagodatskaya, E. and Kuzyakov, Y. 2012. Effects of polyacrylamide, biopolymer, and biochar on decomposition of soil organic matter and plant residues as determined by $14 \mathrm{C}$ and enzyme activities. European J. Soil Biol. 48: 110.

Bailey, V. L., Fansler, S. J., Smith, J. L. and Bolton, H. 2011. Reconciling apparent variability in effects of biochar amendment on soil enzyme activities by assay optimization. Soil Biol. \& Biochem. 43(2): 296-301.

Baligar, V. C. and Bennett, O. L. 1986. Outlook on fertilizer use efficiency in the tropics. Fertilizer Res. 10: 83-96. doi: 10.1007/BF01073907.

Bates, R. B. and Ghoniem, A. F. (2012). Biomass torrefaction: Modeling of volatile and solid product evolution kinetics. Bio.Technol. 124: 460-469.

Blackwell, P., Krull, E., Butler, G., Herbert, A. and Solaiman, Z. 2010. Effect of banded biochar on dryland wheat production and fertiliser use in southwestern Australia: an agronomic and economic perspective. Australian J. Soil Res. 48(6/7): 531-545.

Brandli, R. C., Kupper, T., Bucheli, T. D., Zennegg, M., Huber, S. and Ortelli, D. 2007. Organic pollutants in compost and digestate. Part 2. Polychlorinated dibenzo-p-dioxins, and furans, dioxinlike polychlorinated biphenyls, brominated flame retardants, perfluorinated alkyl substances, pesticides, and other compounds. $J$. Environ. Monit. 9: 465-472.

Brick, S. and Lyutse, S. 2010. Biochar: Assessing the promise and risks to guide US policy, Natural Resources Defense Council Issue Paper. Availableat: http://www. nrdc. org/energy/files/biochar_paper.pdf (accessed: 3 December 2014).

Busscher, W. J., Novak, J. M. and Ahmedna, M. 2011. Physical effects of organic matter amendment of south eastern US coastal loamy sand. Soil Science. 176(12): 661-667.

Chan, K. Y., Heenan, D. P. and So, H. B. 2003. Sequestration of carbon and changes in soil quality under conservation tillage on light-textured soils in Australia: A review. Australian J. Experi. Agri. 43(4): 325-334.

Chan, K. Y., Van, L. Z., Meszaros, I., Downie, A. and Joseph, S. 2007. Agronomic values of green waste biochar as a soil amendment. Australian J. Soil Res. 45: 629-634. 
Chan, K. Y., Van, L. Z., Meszaros, I., Downie, A. and Joseph, S. 2008b. Using poultry litter biochars as soil amendments. Australian J. Soil Res. 46(5): 437-444.

Clough, T. J., Bertram, J. E., Ray, J. L., Condron, L. M., Callaghan, M. O., Sherlock, R. R. and Wells, N. S. 2010. Unweathered wood biochar impact on nitrous oxide emissions from a bovineurine-amended pasture soil. Soil Sci. Soc. America J. 74: 852-860.

Conyers, M. 2012. Soil carbon changes complex and slow. Farming Ahead Kondin in Group. www.kondiningroup. com.au

Cory, A., Kramer, R. L., Indrek, S. W., Ruby, N. and Ghosh. 2009. Time Resolved Measurements of Pyrolysis Products from Thermoplastic Poly-MethylMethacrylate (PMMA) ASME 2009 Intern.Mech. Eng.Cong. and Exp.

Dandie, C. E., Baldock, J. A., Van, L. Z. and Krull, E. 2011. Poultry manure biochar application to a Ferrosol- Effects on $\mathrm{N}$ cycling processes. Proceedings $2^{\text {nd }}$ Asia Pacific Biochar Conference, Kyoto Japan September 2011.

De Gryze, S., Cullen, M. and Durschinger, L. 2010. Evaluation of the opportunities for generating carbon offsets from soil sequestration of biochar: Terra Global Capital.

Downie, A., Crosky, A. and Munroe, P. 2009. Physical properties of biochar. In 'Biochar for environmental management: Science and technology.' (Eds J Lehmann and S Joseph) pp. 1332. Earthscan: London; Sterling, VA, USA.

Dutch Torrefaction Association, 2012. Torrefaction: The future of energy. Dutch Torrefaction Association (DTA). Retrieved February 29, 2012.

Evans, G. 2008. Liquid Transport BiofuelsTechnology

Status
Report" Archived September 19, 2008, at the Wayback Machine., "National Non-Food Crops Centre", 14-04-08.

FAO. 2006. United Nations Food and Agriculture Organization. The State of Food Insecurity in the World, FAO, Rome, www.fao.org/docrep/009/a0750e/a0750 e00.htm, accessed 7 August 2008.

Foley, J. A., DeFries, R., Asner, G. P., Barford, C., Bonan, G., Carpenter, S. R., Chapin, F. S., Coe, M. T., Daily, G. C., Gibbs, H. K., Helkowski, J. H., Holloway, T., Howard, E. A., Kucharik, C. J., Monfreda, C., Patz, J. A., Prentice, I. C., Ramankutty, N. and Snyder, P. K. 2005. Global consequences of land use. Science. 309: 570-574.

Free, H. F., McGill, C. R., Rowarth, J. S. and Hedley, M. J. 2010. The effect of biochars on maize (Zea mays) germination. New Zealand J. Agri. Res. 53(1): $1-4$.

Glaser, B., Lehmann, J. and Zech, W. 2002. Ameliorating physical and chemical properties of highly weathered soils in the tropics with charcoal: A review. Biol. and Ferti. Soils. 35: 219-230.

Human Development Report. 2016. Human Development Report Office estimates based on abridged life-tables of the United Nations Department of Economic and Social Affairs (UNDESA).

IAASTD. 2008. International Assessment of Agricultural Knowledge, Science and Technology for Development, www.agassessment.org, accessed 8 August 2008.

International Biochar Initiative. 2012b. Standardized product definition and product testing guidelines for biochar that is used in soil. Published online May 2012. 
Jin, H. 2010. Characterization of microbial life colonizing biochar and biocharamended soils. Ph.D. Thesis, Cornell University.

Joseph, S. D., Camps, A. M., Lin, Y., Munroe, P., Chia, C. H., Hook, J., Van, L. Z., Kimber, S., Cowie, A., Singh, B. P., Lehmann, J., Foid, L., Smernik, R. J. and Amonette, J. E. 2010. An investigation into the reactions of biochar in soil. Australian J. Soil Res. 48(6/7): 501-515.

Keith, A., Singh, B. and Singh, B. P. 2011. Interactive priming of biochar and labile organic matter mineralization in a smectite-rich soil. Environ. Sci. Tech. 45(22): 9611-9618.

Keller, M. L., Masiello, C. A., Dugan, B., Rudgers, J. A. and Capareda, S. C. 2010. Phytotoxicity and plant productivity analysis of tar-enriched biochars. In 'American Geophysical Union, Fall Meeting 2008, abstract \#B23D-0481,' http://adsabs.harvard. edu/abs/2008AGUFM.B23D0481K.

Kuzyakov, Y., Subbotina, I., Chen, H., Bogomolova, I. and Xu, X. 2009. Black carbon decomposition and incorporation into soil microbial biomass estimated by 14C labeling. Soil Biol. \& Biochem. 41(2): 210-219.

Kwapinski, W., Byrne, C. M. P., Kryachko, E., Wolfram, P., Adley, C., Leahy, J. J., Novotny, E. H. and Hayes, M. H. B. 2010. Biochar from biomass and waste. Waste Bio. Valor. 1: 177-189.

Laird, D. A. 2008. The charcoal vision: A win-win-win scenario for simultaneously producing bioenergy, permanently sequestering carbon, while improving soil and water quality. Agron. J. 100: 178-181.

Lehmann, J. 2007. Bio-energy in the black. Frontiers of Eco. Environ. 5: 381-387.

Lehmann, J., Czimczik, C., Laird, D. and Sohi, S. 2009. Stability of biochar in soil, Biochar for Environmental Management: Science and Tech. pp. 183-206.

Lehmann, J., Gaunt, J. and Rondon, M. 2006. Bio-char sequestration in terrestrial ecosystems: A review, Mitig. Adapt. Strat. Gl. 11: 403-427.

Lehmann, J., Rillig, M. C., Thies, J., Masiello, C. A., Hockaday, W. C. and Crowley, D. 2011. Biochar effects on soil biota: A review. Soil Biol. Biochem. 43: 1812-1836.

Liesch A. M., Weyers, S. L., Gaskin, J. and Das, K. C. 2010. Impact of two different biochars on earthworm growth and survival. Annals Environ. Sci. 4: 19.

Lin, Y., Munroe, P., Joseph, S., Kimber, S. and Van, L. Z. 2012. Nanoscale organomineral reactions of biochars in ferrosol: An investigation using microscopy. Plant and Soil. DOI: 10.1007/s11104-012-1169-8

Luo, L., Lou, L. P., Cui, X. Y., Wu, B. B., Hou, J., Xun, B., Xu, X. H., and Chen, Y. X. 2011. Sorption and desorption of pentachlorophenol to black carbon of three different origins. J. Hazard. Mater. 185: 639-646.

Luo, Y., Durenkamp, M., Nobili, M., Lin, Q. and Brookes, P. C. 2011. Short term soil priming effects and the mineralisation of biochar following its incorporation to soils of different $\mathrm{pH}$. Soil Biol. Biochem. 43(11): 2304-2314.

Marris, E. 2006. Putting the carbon back: black is the new green. Nature. 442: 624-626.

Matovic, D. 2011. Biochar as a viable carbon sequestration option: Global and Canadian perspective. Energy. 36(4): 2011-2016.

Matson, P. A., Parton, W. J., Power, A. G. and Swift, M. J. 1997. Agricultural intensification and ecosystem properties. Science. 277: 504-509. 
McBeath, A. V. and Smernik, R. J. 2009. Variation in the degree of aromatic condensation of chars. Organic Geochem. 40(12): 1161-1168.

Meyer S., Glaser, B. and Quicker, P. 2011. Technical, economical, and climaterelated aspects of biochar production technologies: A literature review. Environ. Sci. Tech. 45(22): 9473-9483.

Nguyen, B. T. and Lehmann, J. 2009. Black carbon decomposition under varying water regimes. Organic Geochem. 40(8): 846-853.

Nguyen, B. T., Lehmann, J., Hockaday, W. C., Joseph, S. and Masiello, C. A. 2010. Temperature sensitivity of black carbon decomposition and oxidation. Environ. Sci. Tech. 44(9): 3324-3331.

Ogawa, M. and Okimori, Y. 2010. Pioneering works in biochar research, Japan. Australian J. Soil Res. 48(6/7): 489-500.

Rogovska, N., Laird, D., Cruse, R. and Heaton, E. 2010. Evaluation of biochar quality utilizing standard germination test. In 'Green Revolution 2.0: Food+energy and environmental security. Proceedings of the ASA, CSSA and SSSA 2010, International Annual Meeting. Long Beach, California

Singh B. P. and Cowie, A. L. 2010. The mean turnover time of biochar in soil varies depending on biomass source and pyrolysis temperature. In 'Soil solutions for a changing world.' 19th World Congress of Soil Science, 1-6 August 2010, Brisbane, Australia. Viewed 1 December 2010 at http://www.iuss.org/ 19th\%20WCSS/Symposium/pdf/0326.p df.

Singh B., Singh, B. P. and Cowie, A. L. 2010. Characterisation and evaluation of biochars for their application as a soil amendment. Australian J. Soil Res. 48(6/7): 516-525.
Slavich P. G., Sinclair, K., Morris, S. G., Kimber, S. W. L., Downie, A. and Van, L. Z. 2012. Contrasting effects of manure and green waste biochars on the properties of an acidic ferralsol and productivity of a subtropical pasture. Plant and Soil. 366(1-2): 213-227.

Sparkes, J. and Stoutjesdijk, P. 2011. Biochar: Implications for agricultural productivity. ABARES technical report 11.6. Australian Bureau of Agricultural and Resource Economics and Sciences, Canberra.

Steiner, C., Glaser, B., Teixeira, W. G., Lehmann, J., Blum, W. E. H. and Zech, W. 2008. Nitrogen retention and plant uptake on a highly weathered central Amazonian Ferralsol amended with compost and charcoal. J. Plant Nutr. Soil Sci. 171(6): 893-899.

Stocking, M. A. 2003. Tropical soils and food security: The next 50 years. Science. 302: 356-359.

Streubel, J. D., Collins, H. P., Garcia-Perez, M., Tarara, J., Granatstein, D. and Kruger, C. E. 2011. Influence of contrasting biochar types on five soils at increasing rates of application. Soil Sci. Soc. America J. 75(4): 1402-1413.

Tryon, E. H. 1948. Effect of charcoal on certain physical, chemical, and biological properties of forest soils. Ecol.Monographs. 18: 81-115.

Uzoma, K. C., Inoue, M., Andry, H., Zahoor, A. and Nishihara, E. 2011. Influence of biochar application on sandy soil hydraulic properties and nutrient retention. J. Food Agri. Environ. 9(3/4 part 2): 1137-1143.

Van, L. Z., Kimber, S., Morris, S., Chan, K. Y., Downie, A., Rust, J., Joseph, S. and Cowie, A. 2010c. Effects of biochar from slow pyrolysis of paper mill waste on agronomic performance and soil fertility. Plant and Soil. 327(1/2): 235246. 
Van, L. Z., Kimber, S., Orr, L., Morris, S., Downie, A., Sinclair, K., Joseph, S. and Chan, K. Y. 2009. Agro-economic valuation of biochar using field-derived data. In 'Proceedings of the $1^{\text {st }}$ Asia Pacific Biochar Conference, Watermark Hotel, Gold Coast, Australia, 17-20 May 2009'. NSW Dept of Primary Industries. Orange, N.S.W. p58.

Veeken, A. and Hamelers, B. 2002. Sources of $\mathrm{Cd}, \mathrm{Cu}, \mathrm{Pb}$ and $\mathrm{Zn}$ in biowaste. Sci. Total Environ. 300: 87-98.

Wang T., Camps, A. M., Hedley, M. and Bishop, P. 2012. Predicting phosphorus bioavailability from high-ash biochars. Plant and Soil. 357: 173-187.

Wardle D. A., Nilsson, M. C. and Zackrisson, O. 2008. Fire-derived charcoal causes loss of forest humus. Science. 320(5876): 629 .

Winsley, P. 2007. Biochar and bioenergy production for climate change mitigation. New Zealand Sci. Review. 64: 5-10.

Woolf, D., Amonette, J. E., Street-Perrott, F. A., Lehmann, J., Joseph, S. 2010.
Sustainable biochar to mitigate global climate change. Nature Comm. 1: 5664.

Yao, F. X., Camps, A. M., Virgel, S., Blanco, F., Arostegui, J., Macia-Agullo, J. A. and Maclas, F. 2010. Simulated geochemical weathering of a mineral ash-rich biochar in a modified Soxhlet reactor. Chemosphere. 80: 724-732.

Zheng, W., Guo, M., Chow, T., Bennett, D. N. and Rajagopalan, N. 2010. Sorption properties of green waste biochar from two trizaine pesticides. J. Hazard. Mater. 181: 121-126.

Zimmerman, A. R. 2010. Abiotic and microbial oxidation of laboratoryproduced black carbon (biochar). Environ. Sci. Tech. 44(4): 1295-1301.

Zimmerman, A. R., Gao, B. and Ahn, M. Y. 2011. Positive and negative carbon mineralization priming effects among a variety of biochar-amended soils. Soil Biol. \& Biochem. 43(6): 1169-1179.

\section{How to cite this article:}

Harender Singh Dahiya and Yogendra Kumar Budania. 2018. Biochar: A Potential Alternative for Sustainable Agriculture. Int.J.Curr.Microbiol.App.Sci. 7(10): 410-425. doi: https://doi.org/10.20546/ijcmas.2018.710.044 